\title{
Transcriptional Regulation of RUNX1: An Informatics Analysis
}

\author{
Amarni L. Thomas ${ }^{1}$, Judith Marsman ${ }^{2}\left(\mathbb{D}\right.$, Jisha Antony ${ }^{1,3}$, William Schierding ${ }^{4}\left(\mathbb{D}\right.$, Justin M. O'Sullivan ${ }^{3,4,5}$ (D) and \\ Julia A. Horsfield 1,3,6,*(D)
}

1 Department of Pathology, Dunedin School of Medicine, University of Otago, Dunedin 9016, New Zealand; amarni.thomas@otago.ac.nz (A.L.T.); jisha.antony@otago.ac.nz (J.A.)

2 Department of Cardiology, University Medical Centre Utrecht, 3584 CX Utrecht, The Netherlands; J.Marsman@umcutrecht.nl

3 The Maurice Wilkins Centre for Biodiscovery, The University of Auckland, Private Bag 92019, Auckland 1142, New Zealand; justin.osullivan@auckland.ac.nz

4 Liggins Institute, The University of Auckland, Private Bag 92019, Auckland 1142, New Zealand; w.schierding@auckland.ac.nz

5 MRC Lifecourse Epidemiology Unit, University of Southampton, Southampton SO17 1BJ, UK

6 Genetics Otago Research Centre, University of Otago, Dunedin 9054, New Zealand

* Correspondence: julia.horsfield@otago.ac.nz

check for updates

Citation: Thomas, A.L.; Marsman, J.; Antony, J.; Schierding, W.; O'Sullivan, J.M.; Horsfield, J.A. Transcriptional Regulation of RUNX1: An Informatics Analysis. Genes 2021, 12, 1175. https://doi.org/10.3390/ genes12081175

Academic Editor: Ota Fuchs

Received: 2 June 2021

Accepted: 28 July 2021

Published: 29 July 2021

Publisher's Note: MDPI stays neutral with regard to jurisdictional claims in published maps and institutional affiliations.

Copyright: (c) 2021 by the authors. Licensee MDPI, Basel, Switzerland. This article is an open access article distributed under the terms and conditions of the Creative Commons Attribution (CC BY) license (https:/ / creativecommons.org/licenses/by/ $4.0 /)$.

\begin{abstract}
The RUNX1/AML1 gene encodes a developmental transcription factor that is an important regulator of haematopoiesis in vertebrates. Genetic disruptions to the RUNX1 gene are frequently associated with acute myeloid leukaemia. Gene regulatory elements (REs), such as enhancers located in non-coding DNA, are likely to be important for Runx1 transcription. Non-coding elements that modulate Runx1 expression have been investigated over several decades, but how and when these REs function remains poorly understood. Here we used bioinformatic methods and functional data to characterise the regulatory landscape of vertebrate Runx1. We identified REs that are conserved between human and mouse, many of which produce enhancer RNAs in diverse tissues. Genome-wide association studies detected single nucleotide polymorphisms in REs, some of which correlate with gene expression quantitative trait loci in tissues in which the RE is active. Our analyses also suggest that REs can be variant in haematological malignancies. In summary, our analysis identifies features of the RUNX1 regulatory landscape that are likely to be important for the regulation of this gene in normal and malignant haematopoiesis.
\end{abstract}

Keywords: acute myeloid leukaemia; RUNX1; transcription; enhancer; silencer; chromatin

\section{Introduction}

Accurate spatiotemporal and quantitative gene expression is crucial for normal development and, in many cases, is achieved by the interaction of promoters with cis-regulatory elements (REs). REs, such as enhancers, are able to control the expression of genes by long-range chromatin interactions [1,2].

Most REs evolve rapidly and are rarely conserved at the DNA sequence level among species due to positive evolutionary selection [3]. However, clusters of conserved REs surround some highly conserved developmental genes. REs can be highly tissue-specific, and surprisingly remote from their gene targets [4,5]. Although REs often regulate the closest gene, they can also control expression of genes further afield [6-8]. Fewer than 50\% of enhancers contact the nearest gene promoter [9]. Long-range chromatin interactions between promoters and REs can be mediated by scaffolding proteins and transcription factors (TFs) to regulate gene expression [10]. These factors include those responsible for the three-dimensional organisation of chromatin, such as cohesin and CTCF $[10,11]$. 
The transcription factor Runx1 is crucial for definitive haematopoiesis [12,13]. In humans, the RUNX1 gene is frequently targeted by translocation or mutation in acute myeloid leukaemia (AML) and other myeloproliferative disorders [14-16]. Expression of the Runx1 gene involves two alternative promoters, P1 (distal) and P2 (proximal) (Figure 1). These two promoters are differentially regulated to produce alternative transcripts that are translated into different protein products that function in neuronal as well as haematopoietic development ([17], reviewed in [18]).
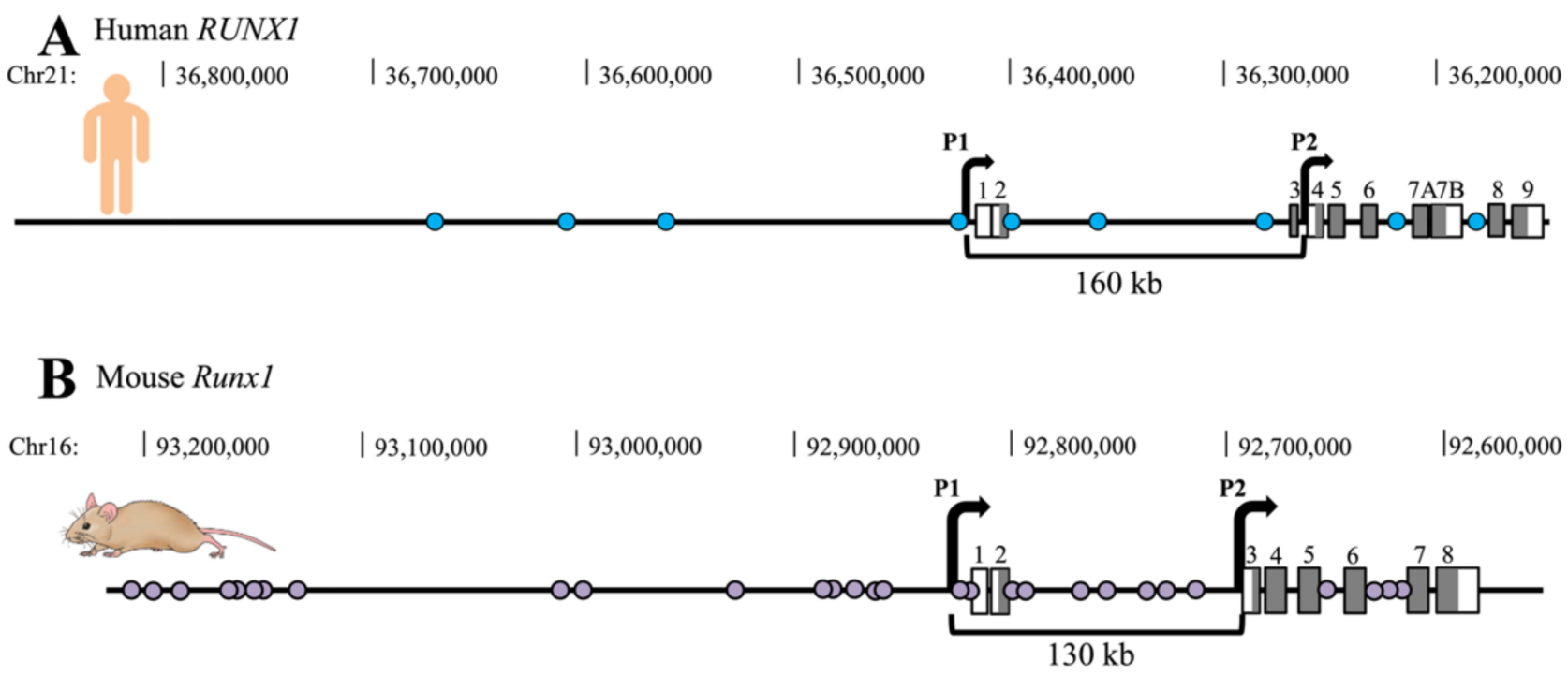

Figure 1. Schematic representing the approximate genomic location of Runx1 regulatory elements (REs) identified to date in human and mouse. REs are annotated with circles; grey boxes annotate exons of Runx1. The two Runx1 promoters are represented by black right angled arrows (A) Genomic location of the 9 previously identified Human RUNX1 REs. (B) Genomic location of the 29 previously identified mouse Runx1 REs.

Both haematopoietic and non-haematopoietic expression of Runx1 appears to rely on REs. For example, the Runx1 promoters by themselves cannot drive haematopoietic expression of Runx1 [19]. Rather, a well-characterised enhancer located 24 kilobases (kb) downstream of the transcription start site of Runx1's P1 promoter regulates Runx1 expression specifically in haematopoietic cells. In mouse, this RE is variously termed $+23 /+24 /$ eR1/RE1 [19-23], and is responsible for the activation of Runx1 expression in haematopoietic stem/progenitor cells. Runx1 +23/+24 also acts as a haemogenic endothelial cell-specific enhancer in mouse and zebrafish embryos and is therefore is highly conserved in eukaryotes [21,23-25]. Bee et al. (2009) showed the $+23 /+24$ enhancer works with both promoters to drive haematopoietic stem cell-specific gene expression [19]. Interestingly, $+23 /+24$ was also described as a silencer in HEK293 cells [23].

Other putative REs were identified upstream of Runx1, and between the P1 and P2 promoters in humans and mice (Figure 1) [21,23-33]. Many of these REs appear to be important for normal haematopoiesis, and dysregulated in leukaemia. Cheng et al. (2018) found that disruption of a RE by chromosomal translocation can upregulate RUNX1 and progress leukaemogenesis [28]. Mill et al. (2019) deleted the whole intron between RUNX1 P1 and P2 in OCI-AML5 cells [34], removing three described REs including $+23 /+24$. The majority of the edited cells were eradicated via apoptosis, and the viable edited cells had significantly decreased RUNX1 expression and slower growth [34].

Recent studies have identified recurrent mutations in REs of genes associated with oncogenesis, such in as the TAL1, ETV1, and PAX5 enhancers [35-37]. In AML and other myeloid malignancies where no mutation is found in the coding sequence, there may instead be mutations in REs that affect gene function, including RUNX1 [38]. Therefore, defining the compendium of conserved Runx1 REs is imperative to understanding the regulatory landscape of $R u n x 1$ in normal and malignant haematopoiesis. 
Here we used bioinformatic methods and functional data to identify possible REs that are conserved between human and mouse. Our analyses also suggest that RUNX1 REs are indeed affected by mutation in haematological malignancies.

\section{Materials and Methods}

\subsection{RE sequence Identification}

Genomic sequences surrounding the Runx1 locus for human (Homo sapiens) and mouse (Mus musculus) were obtained from publicly available genome assemblies [human (GRCh38/hg38 and GRCh37/hg19) assembly, and mouse (mm9 and mm10) assembly] on the UCSC genome browser $[39,40]$. Sequences were determined based on primer information or chromosome coordinates provided in the identifying paper [21,23-33].

\subsection{Epigenetic Analyses Using ENCODE Data}

ENCODE data were used to detect the presence of various histone modifications, DNase I hypersensitivity sites, TFs and cohesin binding sites [27,41-43]. Analysis of ENCODE annotations was carried out using data submitted by Stanford, Yale, University of Washington (UW) and Ludwig Institute for Cancer Research (LICR). To determine the RE locations in different genome assemblies the UCSC 'liftOver' tool was used to convert coordinates within a species [42].To determine the human genome co-ordinates for identified Runx1 enhancers, the sequences were searched using the UCSC BLAT and NCBI BLAST tools [44,45]. Further genomic features of the conserved REs were deduced by analysing the human FANTOM 5 data $[46,47]$ in the UCSC Genome Browser.

Chromatin State predictions (ChromHMM) for K562 cells were used to annotate the REs based on epigenetic information [48]. Further regulatory markers for K562 cells were uploaded into the UCSC genome browser including; super-enhancers [49], silencers [50], cohesin mediated chromatin accessibility [51].

\subsection{Single Nucleotide Polymorphism (SNP) Analysis}

To assess the phenotypic and functional relevance of any reported SNPs in each region, the GWAS catalog (GRCh38/hg38) [52], Catalogue of somatic mutations in cancer (COSMIC) GRCh37/hg19 and GRCh38/hg38) [53], DICE (GRCh37/hg19) [54,55] and HaploReg v4.1 (GRCh37/hg19) [56] were used. The GWAS catalog highlights any publications that report on the association of that SNP with a phenotype. The HaploReg v4.1 tool displays the ChromHMM, genome characteristics, and TF binding data for each SNP and predicts regulatory motif changes. To establish if any SNPs had an association with changes of gene expression (expression Quantitative Trait Loci-eQTL), we searched all SNPs with a minor allele frequency (MAF) of $>1 \%$ in the Genotype-Tissue Expression (GTEx) portal v8 (GRCh38/hg38) (https://gtexportal.org/home/ accessed on 25 June 2021). The gnomAD browser [57] v2.1.1 (GRCh37/hg19) and v3 (GRCh38/hg38) reviewed SNPs with MAF $>1 \%$ for any ClinVar associations and/or publications. To identify physical interactions between SNPs in the REs and genes, the CoDeS3D pipeline [58] was used to interrogate Hi-C chromatin interaction libraries.

\subsection{Comparative Analysis of Cancer Genomic Datasets}

To assess whether AML patients had mutations in the conserved REs, publicly available cancer genomic datasets were explored. Online tools were used to categorise publicly available patient information into different tumour types for analysis. The large-scale cancer genomics datasets were retrieved from International Cancer Genome Consortium (ICGC) Data Portal [human Feb. 2009 (GRCh37/hg19) assembly] (Whole Genome sequence (WGS) data for 1732 AML/MDS donors) [59,60], The c-BioPortal for Cancer Genomics [human Feb. 2009 (GRCh37/hg19) assembly] (50 WGS/451 total AML samples) [61,62], COSMIC database (GRCh37/hg19 and GRCh38/hg38) (39 additional WGS AML samples) [53] and The Cancer Genome Atlas (TCGA) Data Portal [human Mar. 2006 (NCBI36/hg18) assembly] (50 WGS AML samples) [63]. 


\subsection{Prediction the Functional Consequences of Non-Coding Variations}

To predict the pathogenicity of SNPs and cancer associated genetic variations within R1REs Functional Analysis through Hidden Markov Models (FATHMM v2.3) (GRCh37/hg19) was used $[64,65]$.

\section{Results}

\subsection{Conserved Human RUNX1 Regulators}

We first sought to identify enhancers for Run $x 1$ that are conserved between human and mouse. In mice, previously studies identified 29 possible regulators of Runx $1(-371,-368$, $-354,-328,-327,-322,-321,-303,-181,-171,-101,-59,-58,-48,-43,-42,+1,+3$, $+24,+32,+59,+64,+87,+99,+110,+171,+181,+199,+204)[21,24,25,31-33,66]$. Several studies have focused on a strong Runx1 enhancer in mice: Runx1 +23/+24/eR1/RE1 [19-21]. The naming of the element refers to the number of kilobases $(\mathrm{kb})$ downstream of a reference point. The inconsistency of enhancer naming between groups is because Ng et al. (2010) uses the transcriptional start site (TSS), +1 as the reference point [21], whilst the other groups refer to this enhancer being $23.5 \mathrm{~kb}$ downstream from the ATG of exon $1 .+23 /+24$ is also referred to as eR1 (enhancer of $\underline{R} u n x \underline{1}$ [22]), and RE1 (regulatory element $\underline{1}$ [67]). Hereafter, $+23 /+24 / \mathrm{eR} 1 / \mathrm{RE} 1$ will be referred to as $\underline{R} u n x \underline{1}$ regulatory element $\underline{1}$ (R1RE1).

Markova et al. (2011), Cauchy et al. (2015), Gunnell et al. (2016) and Cheng et al. (2018) and Vukadin et al. (2020) identified 9 potential human $\underline{R} U N X \underline{1}$ regulatory elements (R1REs) $(-250,-188,-139,-57,+24,+43,+62,+139$, intron 5.2). Some of these discoveries included functional characterisation and identification of long-range interactions with RUNX1 promoters [23,26,28-30].

When gathering sequence information about these mouse REs we noted that three regions identified by Schütte et al. (2016) are the same as regions described by Marsman et al. (2017): Schütte's - 328 is Marsman's - 327; Schütte's - 322 is Marsman's - 321; and Schütte's - 59 is Marsman's - 58. The Runx1 m+204 sequence sits within the previously described RUNX1 intron 5.2.

Based on sequence analyses we determined that 12 out of the 29 previously identified mouse Runx1 REs are conserved in human. This increases the number of 'known' putative human R1REs from 9 to 21 . The Runx1 enhancers that were identified to be conserved between human and mouse were assigned a common identity, R1RE2-R1RE21, and (other than R1RE1) they are numbered in order of 5' to 3' location relative to the orientation of the Runx1 gene (Table 1).

Table 1. Conserved mouse and human Runx1 regulatory regions.

\begin{tabular}{|c|c|c|c|c|c|}
\hline Name & $\begin{array}{l}\text { Location Relative to } \\
\text { Runx1 P1 (kb) }\end{array}$ & $\begin{array}{c}\text { Genome } \\
\text { Coordinates (Hg19) }\end{array}$ & Identification Methods & $\begin{array}{l}\text { Interactions } \\
\text { Identified }\end{array}$ & Functional Validation \\
\hline R1RE1 & $\begin{array}{l}\text { Mouse and Human } \\
\text { Runx1 relative to P1 } \\
+23 /+24 / \text { eR1/RE1 }\end{array}$ & $\begin{array}{c}\text { chr21: } \\
36399106-36399322\end{array}$ & $\begin{array}{l}\text { Sequence conservation, } \\
\text { DNase I hypersensitive } \\
\text { sites (DHS) }[20,21,23]\end{array}$ & $\begin{array}{l}\text { Interacts with } \\
\text { promoters (P1 and } \\
\text { P2) of Runx1 }[23,25] \text {. }\end{array}$ & $\begin{array}{l}\text { Haematopoietic enhancer } \\
\text { activity in mouse and } \\
\text { zebrafish and enhancer } \\
\text { activity in 416B, K562, Jurkat; } \\
\text { silencer in HEK293 cells } \\
\text { [21,23-25]. }\end{array}$ \\
\hline R1RE2 & mouse -371 & $\begin{array}{c}\text { chr21: } \\
36855111-36856085\end{array}$ & $\begin{array}{l}\text { Interaction with Runx1 } \\
\text { promoters described by } \\
4 \mathrm{C} \text { and TF binding motif } \\
\text { analysis [25]. }\end{array}$ & $\begin{array}{l}\text { Interacts with R1RE1 } \\
\text { and P1 in HPC7 cells } \\
\text { identified by 4C [25]. }\end{array}$ & $\begin{array}{c}\text { Hematopoietic enhancer } \\
\text { activity in 20-24 hpf zebrafish } \\
\text { embryos [25]. } \\
\text { Active in pre-haemogenic } \\
\text { endothelial cells and } \\
\text { intra-arterial clusters in mice } \\
\text { [68]. }\end{array}$ \\
\hline
\end{tabular}


Table 1. Cont

\begin{tabular}{|c|c|c|c|c|c|}
\hline Name & $\begin{array}{l}\text { Location Relative to } \\
\text { Runx1 P1 (kb) }\end{array}$ & $\begin{array}{c}\text { Genome } \\
\text { Coordinates (Hg19) }\end{array}$ & Identification Methods & $\begin{array}{l}\text { Interactions } \\
\text { Identified }\end{array}$ & Functional Validation \\
\hline R1RE3 & mouse -368 & $\begin{array}{c}\text { chr21: } \\
\text { 36849117-36849289 }\end{array}$ & $\begin{array}{c}\text { Sequence conservation } \\
\text { and TF binding motif } \\
\text { analysis [21]. }\end{array}$ & No available data & $\begin{array}{c}\text { Hematopoietic enhancer } \\
\text { activity in 20-24 hpf zebrafish } \\
\text { embryos [25]. }\end{array}$ \\
\hline $\mathrm{N} / \mathrm{A}$ & mouse -354 & Not conserved & $\begin{array}{c}\text { Interaction with Runx1 } \\
\text { promoters (4C) and TF } \\
\text { binding motif analysis } \\
\text { [25]. }\end{array}$ & $\begin{array}{c}\text { Interacts with R1RE1 } \\
\text { and P1 in HPC7 cells } \\
{[25,27] .}\end{array}$ & $\begin{array}{l}\text { Hematopoietic enhancer } \\
\text { activity in 20-24 hpf zebrafish } \\
\text { embryos [25]. }\end{array}$ \\
\hline
\end{tabular}

Interaction with Runx1

promoters (4C) and TF

binding motif analysis

R1RE4 mouse -327 chr21: [25]. Recruits TFs (ERG

[25]/-328 [24] 36800068-36801396 FLI1, GATA2, GFI1B

LYL1, MEIS1, SPI1,

RUNX1 and TAL1) and H3K27ac [24]

Interaction with Runx 1

promoters (4C) and TF

binding motif analysis

$\begin{array}{ccc}\text { Nouse }-321 & \text { Not conserved }\end{array}$

[25]. Recruits TFs (ERG,

FLI1, GATA2, GFI1B,

LYL1, MEIS1, SPI1,

RUNX1 and TAL1) and

H3K27ac [24]

\begin{tabular}{|c|c|c|c|c|c|}
\hline $\mathrm{N} / \mathrm{A}$ & mouse -303 & Not conserved & $\begin{array}{l}\text { Interaction with Runx1 } \\
\text { promoters }(4 \mathrm{C}) \text { and } \mathrm{TF} \\
\text { binding motif analysis } \\
\text { [25]. }\end{array}$ & $\begin{array}{l}\text { Interacts with R1RE1 } \\
\text { and P2 in HPC7 cells } \\
{[25,27] .}\end{array}$ & $\begin{array}{l}\text { Hematopoietic enhancer } \\
\text { activity in 20-24 hpf zebrafish } \\
\text { embryos and in keratinocytes } \\
\text { from } 20 \text { hpf [25]. }\end{array}$ \\
\hline R1RE5 & human $-250 /$ E6 & $\begin{array}{c}\text { chr21: } \\
36669712-36670621\end{array}$ & Recruits EBNA2 [26]. & No available data & $\begin{array}{c}\text { Enhancer activity in GM12878 } \\
\text { and EBV positive Burkitt's } \\
\text { Lymphoma cell lines [26]. }\end{array}$ \\
\hline R1RE6 & mouse -181 & $\begin{array}{c}\text { chr21: } \\
\text { 36629105-36629568 }\end{array}$ & $\begin{array}{l}\text { Recruits H3K27Ac and } \\
\text { TFs (EOMES, SCL) [33]. }\end{array}$ & No available data & No available data \\
\hline R1RE7 & human $-188 / E 4$ & $\begin{array}{c}\text { chr21: } \\
\text { 36608329-36608806 }\end{array}$ & Recruits EBNA2 [26]. & No available data & $\begin{array}{c}\text { Enhancer activity in GM12878 } \\
\text { and EBV positive Burkitt's } \\
\text { Lymphoma cell lines. [26]. }\end{array}$ \\
\hline $\mathrm{N} / \mathrm{A}$ & mouse -171 & Not conserved & $\begin{array}{l}\text { Recruits H3K27Ac and } \\
\text { TFs (EOMES, SCL) [33]. }\end{array}$ & No available data & No available data \\
\hline R1RE8 & human -139/E1 & $\begin{array}{c}\text { chr21: } \\
36561619-36562555\end{array}$ & Recruits EBNA2 [26]. & No available data & $\begin{array}{c}\text { Enhancer activity in GM12878 } \\
\text { and EBV positive Burkitt's } \\
\text { Lymphoma cell lines [26]. }\end{array}$ \\
\hline R1RE9 & mouse -101 & $\begin{array}{c}\text { chr21: } \\
36542872-36543055\end{array}$ & $\begin{array}{l}\text { Sequence conservation } \\
\text { and TF binding motif } \\
\text { analysis [21] }\end{array}$ & No available data & No available data \\
\hline R1RE10 & $\begin{array}{c}\text { mouse }-58[25] /-59 \\
{[24]}\end{array}$ & $\begin{array}{c}\text { chr21: } \\
36478706-36478906\end{array}$ & $\begin{array}{c}\text { Interaction with Runx1 } \\
\text { promoters (4C) and TF } \\
\text { binding motif analysis } \\
\text { [25]. Recruits TFs (ERG, } \\
\text { FLI1, GATA2, GFI1B, } \\
\text { LYL1, MEIS1, SPI1, } \\
\text { RUNX1 and TAL1) and } \\
\text { H3K27ac [24] }\end{array}$ & $\begin{array}{l}\text { Interacts with R1RE1 } \\
\text { and P1 in HPC7 cells } \\
\text { [25]. }\end{array}$ & $\begin{array}{l}\text { Haematopoietic enhancer } \\
\text { activity in E11.5 transgenic } \\
\text { mice and enhancer activity in } \\
\text { 416B cells [24]. } \\
\text { Hematopoietic enhancer } \\
\text { activity in 20-24 hpf zebrafish } \\
\text { embryos [25] }\end{array}$ \\
\hline $\mathrm{N} / \mathrm{A}$ & mouse -48 & Not conserved & $\begin{array}{c}\text { Interaction with Runx } 1 \\
\text { promoters }(4 C) \text { and TF } \\
\text { binding motif analysis } \\
\text { [25]. }\end{array}$ & $\begin{array}{l}\text { Interacts with R1RE1 } \\
\text { and P1 in HPC7 cells } \\
\text { [25]. }\end{array}$ & $\begin{array}{c}\text { Hematopoietic enhancer } \\
\text { activity in 20-24 hpf zebrafish } \\
\text { embryos [25]. }\end{array}$ \\
\hline R1RE11 & mouse -43 & $\begin{array}{c}\text { chr21: } \\
36464084-36464260\end{array}$ & $\begin{array}{c}\text { Recruits TFs (ERG, FLI1, } \\
\text { GATA2, GFI1B, LYL1, } \\
\text { MEIS1, SPI1, RUNX1 and } \\
\text { TAL1) and H3K27ac [24] }\end{array}$ & No available data & $\begin{array}{l}\text { No enhancer activity in mice } \\
\text { [24]. }\end{array}$ \\
\hline
\end{tabular}

Interacts with R1RE1 No enhancer activity in mice
and P1 in HPC7 cells $[25,27]$.

[24] or zebrafish [25].
Interacts with R1RE1

and P1 in HPC7 cells $[25,27]$.
Identified, but not tested for enhancer activity [24].

Hematopoietic enhancer activity in 20-24 hpf zebrafish embryos [25]. 
Table 1. Cont

\begin{tabular}{|c|c|c|c|c|c|}
\hline Name & $\begin{array}{l}\text { Location Relative to } \\
\text { Runx1 P1 (kb) }\end{array}$ & $\begin{array}{c}\text { Genome } \\
\text { Coordinates (Hg19) }\end{array}$ & Identification Methods & $\begin{array}{l}\text { Interactions } \\
\text { Identified }\end{array}$ & Functional Validation \\
\hline $\mathrm{N} / \mathrm{A}$ & mouse -42 & Not conserved & $\begin{array}{c}\text { Recruits TFs (ERG, FLI1, } \\
\text { GATA2, GFI1B, LYL1, } \\
\text { MEIS1, SPI1, RUNX1 and } \\
\text { TAL1) and H3K27ac [24] }\end{array}$ & No available data & $\begin{array}{l}\text { No enhancer activity in mice } \\
\text { [24]. }\end{array}$ \\
\hline R1RE12 & human -5 & $\begin{array}{c}\text { chr21: } \\
36423511-36423652\end{array}$ & $\begin{array}{l}\text { SON binding in MEG-01 } \\
\text { and CMY cells [29] }\end{array}$ & No available data & No available data \\
\hline $\mathrm{N} / \mathrm{A}$ & mouse +1 & Not conserved & $\begin{array}{c}\text { Recruits TFs (ERG, FLI1, } \\
\text { GATA2, GFI1B, LYL1, } \\
\text { MEIS1, SPI1, RUNX1 and } \\
\text { TAL1) and H3K27ac [24] }\end{array}$ & No available data & No available data \\
\hline R1RE13 & mouse +3 & $\begin{array}{c}\text { chr21: } \\
36418472-36418744\end{array}$ & $\begin{array}{l}\text { Recruits TFs (ERG, FLI1, } \\
\text { GATA2, GFI1B, LYL1, } \\
\text { MEIS1, SPI1, RUNX1 and } \\
\text { TAL1) and H3K27ac [24] }\end{array}$ & No available data & $\begin{array}{c}\text { Haematopoietic enhancer } \\
\text { activity in E11.5 transgenic } \\
\text { mice and enhancer activity in } \\
\text { 416B cells [24]. }\end{array}$ \\
\hline R1RE14 & mouse +32 & $\begin{array}{c}\text { chr21: } \\
36384185-36384451\end{array}$ & $\begin{array}{c}\text { Sequence conservation } \\
\text { and TF binding motif } \\
\text { analysis [21] }\end{array}$ & No available data & No available data \\
\hline R1RE15 & human +62 & $\begin{array}{c}\text { chr21: } \\
\text { 36358933-36359953 }\end{array}$ & $\begin{array}{l}\text { ChIA-PET (RNA } \\
\text { polymerase II) and DHS; } \\
\text { conserved sites for } \\
\text { GFI1/GFI1B and SNAI1. }\end{array}$ & $\begin{array}{l}\text { Interacts with P2 in } \\
\text { K562 and OCl-AML3 } \\
\text { cell lines [28] }\end{array}$ & $\begin{array}{c}\text { Silencer activity in K562, } \\
\text { OCl-AML3, U937 cell lines } \\
\text { [28]. }\end{array}$ \\
\hline R1RE16 & mouse +59 & $\begin{array}{c}\text { chr21: } \\
\text { 36346597-36346844 }\end{array}$ & $\begin{array}{l}\text { Sequence conservation } \\
\text { and TF binding motif } \\
\text { analysis [21] }\end{array}$ & No available data & No available data \\
\hline $\mathrm{N} / \mathrm{A}$ & mouse +64 & Not conserved & $\begin{array}{l}\text { Sequence conservation } \\
\text { and TF binding motif } \\
\text { analysis [21] }\end{array}$ & No available data & No available data \\
\hline R1RE17 & mouse +87 & $\begin{array}{c}\text { chr21: } \\
36310873-36311013\end{array}$ & $\begin{array}{c}\text { Sequence conservation } \\
\text { and TF binding motif } \\
\text { analysis [21] }\end{array}$ & No available data & No available data \\
\hline $\mathrm{N} / \mathrm{A}$ & mouse +99 & Not conserved & $\begin{array}{c}\text { Sequence conservation } \\
\text { and TF binding motif } \\
\text { analysis [21] }\end{array}$ & No available data & No available data \\
\hline R1RE18 & $\begin{array}{c}\text { mouse }+110 \\
{[21] / \text { human }+139} \\
{[29]}\end{array}$ & $\begin{array}{c}\text { chr21: } \\
36280710-36281200\end{array}$ & $\begin{array}{l}\text { Sequence conservation } \\
\text { and TF binding motif } \\
\text { analysis [21]. SON } \\
\text { binding in MEG-01, CMY, } \\
\text { and CMK cells; increased } \\
\text { H3K4 methylation upon } \\
\text { SON depletion [29] }\end{array}$ & $\begin{array}{l}\text { Interacts with P1 in } \\
\text { HPC7 cells identified } \\
\text { by } 4 C \text { [25]. }\end{array}$ & $\begin{array}{c}\text { Haematopoietic enhancer } \\
\text { activity in E11.5 transgenic } \\
\text { mice and enhancer activity in } \\
\text { 416B cells [24]. Hematopoietic } \\
\text { enhancer activity in 20-24 hpf } \\
\text { zebrafish embryos [25]. }\end{array}$ \\
\hline R1RE19 & $\begin{array}{c}\text { mouse }+171 \\
\text { [32]/human }+43 \mathrm{~kb} \\
{[30]}\end{array}$ & $\begin{array}{c}\text { chr21: } \\
36218040-36218420\end{array}$ & $\begin{array}{c}\text { DHS specific to AML } \\
\text { samples (FLT3-ITD) [30]. } \\
\text { GATA3 binding [32] }\end{array}$ & No available data & $\begin{array}{l}\text { Enhancer activity in } \\
\text { UG26-1B6 cells [32] }\end{array}$ \\
\hline $\mathrm{N} / \mathrm{A}$ & mouse +181 & Not conserved & $\begin{array}{l}\text { Recruits TFs (ERG, FLI1, } \\
\text { GATA2, GFI1B, LYL1, } \\
\text { MEIS1, SPI1, RUNX1 and } \\
\text { TAL1) and H3K27ac [24] }\end{array}$ & No available data & $\begin{array}{l}\text { No enhancer activity in mice } \\
\text { [24]. }\end{array}$ \\
\hline R1RE20 & mouse +199 & $\begin{array}{c}\text { chr21: } \\
36186002-36186045\end{array}$ & $\begin{array}{l}\text { Sequence conservation, } \\
\text { p63 binding [31] }\end{array}$ & No available data & $\begin{array}{c}\text { Enhancer activity in PTK2 } \\
\text { cells [31] }\end{array}$ \\
\hline R1RE21 & $\begin{array}{c}\text { human intron } 5.2[23] \\
\text { containing mouse } \\
+204[24]\end{array}$ & $\begin{array}{c}\text { chr21: } \\
36179311-36181581\end{array}$ & $\begin{array}{c}\text { Sequence conservation; } \\
\text { DHS, [23] } \\
\text { Recruits TFs (ERG, FLI1, } \\
\text { GATA2, GFI1B, LYL1, } \\
\text { MEIS1, SPI1, RUNX1 and } \\
\text { TAL1) and H3K27ac [24] }\end{array}$ & $\begin{array}{l}\text { Interacts with P1 and } \\
\text { P2 in K562, Jurkat, } \\
\text { HEK293 cell lines [23] }\end{array}$ & $\begin{array}{c}\text { No enhancer or silencer } \\
\text { activity observed in K562, } \\
\text { Jurkat and HEK293 cell lines } \\
\text { [23]. } \\
\text { Haematopoietic enhancer } \\
\text { activity in E11.5 transgenic } \\
\text { mice and enhancer activity in } \\
\text { 416B cells [24]. }\end{array}$ \\
\hline
\end{tabular}


Conservation between mice and humans suggests that these REs are fundamental for the correct regulation of RUNX1. To determine possible regulatory function in human haematopoietic cells, bioinformatic analysis of R1REs in K562 chronic myelogenous leukaemia cells was undertaken (Table 2, Figure 2). K562 cells express RUNX1 and are comprehensively annotated in ENCODE. Our analysis showed that not all R1REs appear to be active in K562 cells. Moreover, the accessibility of some REs was altered upon cohesin mutation, indicating that cohesin's role in 3D genome structure might influence the function of some REs.

Table 2. Annotations of identified R1REs in K562 cells.

\begin{tabular}{|c|c|c|c|c|}
\hline Name & $\begin{array}{l}\text { Location Relative to } \\
\text { Runx1 P1 (kb) }\end{array}$ & ENCODE Annotation & ChromHMM Annotation & $\begin{array}{c}\text { Altered ATAC } \\
\text { Accessibility in Cohesin } \\
\text { STAG2-/- }\end{array}$ \\
\hline R1RE1 & $\begin{array}{l}\text { mouse and human } R u n x 1 \\
\text { relative to P1 } \\
+23 /+24 / \mathrm{eR} 1 / \mathrm{RE} 1\end{array}$ & $\begin{array}{c}\text { DHS, RNA Pol II, SMC3, CTCF, p300, } \\
\text { LSD1, H3K27ac, H3K4me1, } \\
\text { H3K4me3, H3K9ac, H3K9me3, } \\
\text { GATA1, SPI1, TAL1, GATA2 }\end{array}$ & Strong Enhancer & No change \\
\hline R1RE2 & mouse -371 & $\begin{array}{c}\text { DHS, RNA Pol II, CTCF, p300, LSD1, } \\
\text { H3K27ac, H3K4me1, H3K4me3, } \\
\text { H3K9ac, H3K9me3, H3K27me3, } \\
\text { GATA1, TAL1, GATA2 }\end{array}$ & Strong Enhancer & Increased \\
\hline R1RE3 & mouse -368 & $\begin{array}{l}\text { RNA Pol II, p300, LSD1, H3K27ac, } \\
\text { H3K4me1, H3K4me3, H3K9ac, } \\
\text { H3K9me3, H3K27me3 }\end{array}$ & Strong Enhancer & No change \\
\hline R1RE4 & $\begin{array}{c}\text { mouse }-327[25] /-328 \\
{[24]}\end{array}$ & $\begin{array}{c}\text { p300, H3K4me1, H3K9ac, H3K9me3, } \\
\text { H3K27me3 }\end{array}$ & Repressed & No change \\
\hline R1RE5 & human -250/E6 & $\begin{array}{l}\text { RNA Pol II, p300, LSD1, H3K9me3, } \\
\text { H3K27me3 }\end{array}$ & Repressed & No change \\
\hline R1RE6 & mouse -181 & $\begin{array}{c}\text { DHS, RNA Pol II, p300, } \\
\text { LSD1,H3K27ac, H3K4me1, } \\
\text { H3K4me3, H3K9ac, H3K9me3 }\end{array}$ & Weak Enhancer & Increased \\
\hline R1RE7 & human -188/E4 & $\begin{array}{l}\text { p300, H3K4me3, H3K9me3, } \\
\text { H3K27me3, SPI1 }\end{array}$ & Transcription Associated & No change \\
\hline R1RE8 & human -139/E1 & $\begin{array}{c}\text { p300, H3K4me1, H3K4me3, H3K9ac, } \\
\text { H3K9me3, SPI1 }\end{array}$ & $\begin{array}{c}\text { Weak enhancer, } \\
\text { Transcription Associated }\end{array}$ & No change \\
\hline R1RE9 & mouse -101 & $\begin{array}{l}\text { RNA Pol II, p300, LSD1, H3K27ac, } \\
\text { H3K4me1, H3K4me3, H3K9me3, }\end{array}$ & Transcription Associated & No change \\
\hline R1RE10 & mouse $-58[25] /-59[24]$ & $\begin{array}{c}\text { DHS, RNA Pol II, CTCF, p300, LSD1, } \\
\text { H3K27ac, H3K4me1, H3K4me3, } \\
\text { H3K9ac, H3K9me3, GATA1, TAL1, } \\
\text { GATA2 }\end{array}$ & Strong Enhancer & No change \\
\hline R1RE11 & mouse -43 & $\begin{array}{l}\text { RNA Pol II, CTCF, p300, LSD1, } \\
\text { H3K4me3, H3K9ac, H3K9me3 }\end{array}$ & Weak Enhancer & No change \\
\hline R1RE12 & human -5 & $\begin{array}{l}\text { DHS, RNA Pol II, RAD21, CTCF, } \\
\text { p300, LSD1, H3K27ac, H3K4me1, } \\
\text { H3K4me3, H3K9ac, H3K9me3 }\end{array}$ & Strong Enhancer & No change \\
\hline R1RE13 & mouse +3 & $\begin{array}{l}\text { RNA Pol II, CTCF, p300, LSD1, } \\
\text { H3K4me1, H3K4me3, H3K9ac, } \\
\text { H3K9me3 }\end{array}$ & Transcription Associated & No change \\
\hline R1RE14 & mouse +32 & $\begin{array}{c}\text { DHS, RNA Pol II, p300, } \\
\text { LSD1,H3K4me1, H3K4me3, H3K9ac, } \\
\text { H3K9me3 }\end{array}$ & Weak Enhancer & No change \\
\hline R1RE15 & human +62 & $\begin{array}{c}\text { DHS, RNA Pol II, CTCF, p300, LSD1, } \\
\text { H3K4me1, H3K4me3, H3K9ac, } \\
\text { H3K9me3, H3K27me3 }\end{array}$ & Weak Enhancer & No change \\
\hline
\end{tabular}


Table 2. Cont

\begin{tabular}{|c|c|c|c|c|}
\hline Name & $\begin{array}{l}\text { Location Relative to } \\
\text { Runx1 P1 (kb) }\end{array}$ & ENCODE Annotation & ChromHMM Annotation & $\begin{array}{c}\text { Altered ATAC } \\
\text { Accessibility in Cohesin } \\
\text { STAG2-/- }\end{array}$ \\
\hline R1RE16 & mouse +59 & $\begin{array}{c}\text { RNA Pol II, CTCF, p300, } \\
\text { LSD1,H3K4me1, H3K4me3, H3K9ac, } \\
\text { H3K9me3 }\end{array}$ & Weak Enhancer & No change \\
\hline R1RE17 & mouse +87 & $\begin{array}{l}\text { RNA Pol II, CTCF, p300, LSD1, } \\
\text { H3K4me1, H3K4me3, H3K9me3 }\end{array}$ & Weak Enhancer & No change \\
\hline R1RE18 & $\begin{array}{c}\text { mouse }+110[21] / \text { human } \\
+139[29]\end{array}$ & $\begin{array}{c}\text { DHS, RNA Pol II, RAD21, p300, } \\
\text { LSD1, H3K27ac, H3K4me1, } \\
\text { H3K4me3, H3K9ac, H3K9me3, } \\
\text { H3K27me3 GATA1, TAL1, GATA2 }\end{array}$ & Strong Enhancer & Increased \\
\hline R1RE19 & $\begin{array}{c}\text { mouse }+171[32] / \text { human } \\
+143[30]\end{array}$ & $\begin{array}{c}\text { DHS, RNA Pol II, CTCF, p300, LSD1, } \\
\text { H3K27ac, H3K4me1, H3K9ac, SPI1, } \\
\text { TAL1 }\end{array}$ & Transcription Associated & No change \\
\hline R1RE20 & mouse +199 & $\begin{array}{l}\text { RNA Pol II, CTCF, p300, LSD1, } \\
\text { H3K9me3 }\end{array}$ & Transcription Associated & No change \\
\hline R1RE21 & $\begin{array}{c}\text { human intron } 5.2[23] \\
\text { containing mouse }+204 \\
{[24]}\end{array}$ & $\begin{array}{c}\text { DHS, RNA Pol II, CTCF, p300, LSD1, } \\
\text { H3K27ac, H3K4me1H3K9ac, } \\
\text { H3K9me3, H3K27me3 }\end{array}$ & Transcription Associated & Increased \\
\hline
\end{tabular}

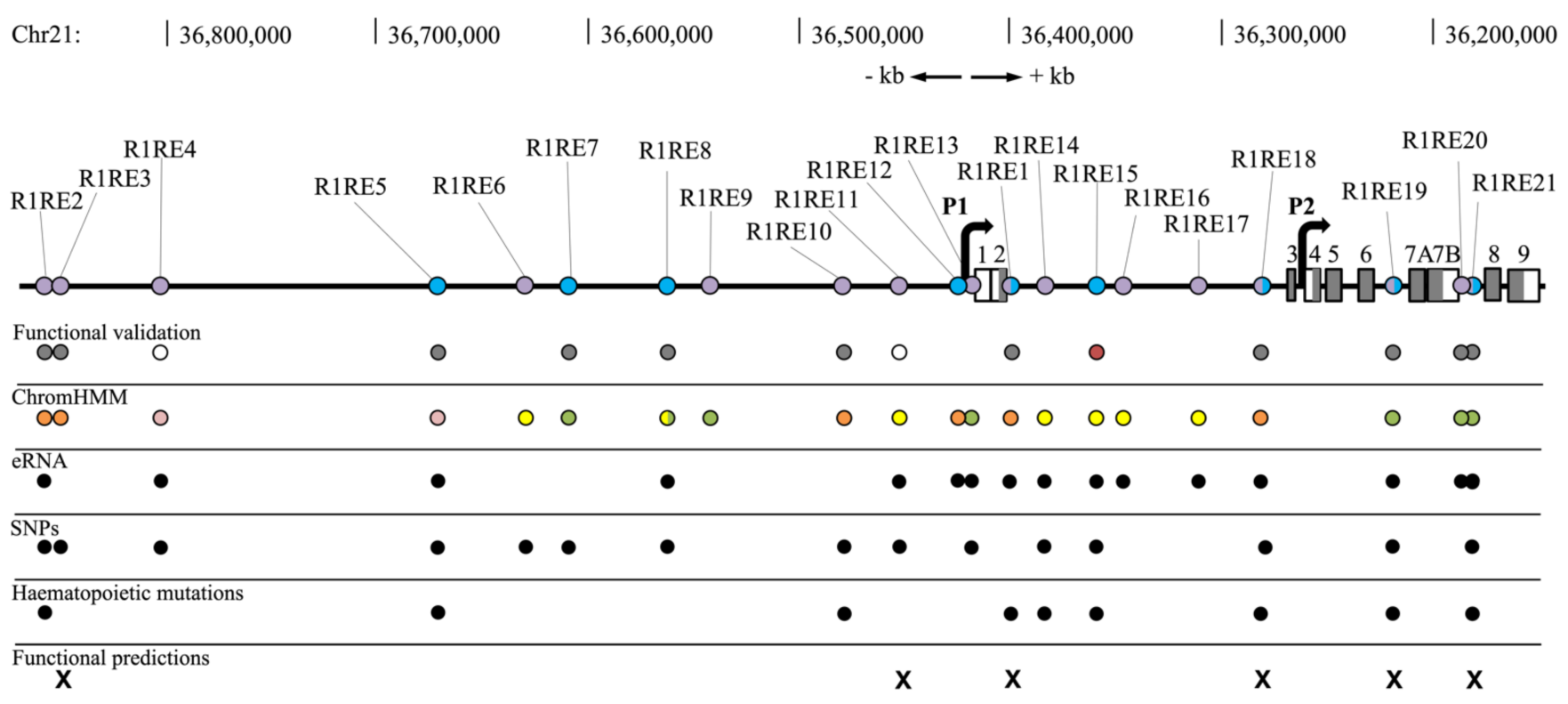

$\begin{array}{ll}\text { Key: } \bigcirc \text { Human origin } & \bigcirc \text { Strong Enhancer } \\ \bigcirc \text { Mouse origin } & \bigcirc \text { Weak Enhancer } \\ \bigcirc \text { Validated enhancer } & \bigcirc \text { Transcription associated } \\ \bigcirc \text { No enhancer activity } & \bigcirc \text { Repressed } \\ \bigcirc \text { Silencer activity } & \mathbf{X} \text { Pathogenic }\end{array}$

Figure 2. Schematic overview of human RUNX1 locus and annotations (chromosome 21: 36,148,773-36,872,777). Each RE with human origin is annotated with blue circles, REs with mouse origin are annotated with purple circles, grey boxes annotate exons. The two RUNX1 promoters are represented by black right angled arrows. R1REs are annotated with their functional validation, ChromHMM characterisation, ability to produce eRNA, SNP status, functional predictions and whether they harbour mutations present in haematopoietic patients. Key for ChromHMM is in the bottom left of the diagram. 


\subsection{Chromatin Features of R1REs}

ChromHMM indicates that R1RE4 and R1RE5 are in repressed chromatin, and that R1REs 1-3, 6, 8, 10-12, and 14-18 are active enhancers. R1REs 9, 13, 19 and 21 show chromatin features of enhancers; however, they are labelled as transcription-associated alongside R1REs 7, 8 and 20 (Table 2, Figure 2). Transcription association may be due to R1RE proximity with exons when compared to the regions annotated as enhancers or it may indicate that these regions are producing RNA, for instance enhancer RNA (eRNA).

R1RE1 has strong enhancer characteristics and recruits haematopoietic TFs SPI1, TAL1, GATA1 and GATA2. SPI1 also located to R1REs 7, 8 and 19. R1RE19 also recruits TAL1 in haematopoietic progenitors. Haematopoietic TFs TAL1, GATA1 and GATA2 bind to R1REs 2, 10 and 18. These regions showed TF binding sites and chromatin modifications similar to that found at R1RE1 (Table 1, Figure 2).

R1RE1 also recruits LSD1, a mediator of transcriptional repression usually seen in silencers. Interestingly, 17 other REs (R1REs 2, 3, 5, 6, and 9-21) had LSD1 binding in K562 cells. Cheng et al. (2018) inhibited LSD1 in three haematopoietic cell lines (K562, OCI-AML3 and U937) and observed upregulation of RUNX1, implying that LSD1 normally represses RUNX1 [28]. Kerenyi et al. (2013) previously showed Lsd1 represses key haematopoietic stem cell genes including Runx1 [69].

Mouse ATAC-seq [66] highlighted altered accessibility at R1REs in different cell types. R1REs 1, 4, 6, 10, 13 and 18 were accessible in mesoderm cells; whereas R1REs 1, 10, 13, 18 , and 21 were accessible in haematopoietic progenitor cells (HPC). These data reflect differential tissue-specific activity of R1REs.

ATAC-seq in K562 cells with a null mutation in the STAG2 gene, which encodes a cohesin subunit [51], showed that R1REs 2, 6, 18 and 21 regions reside in differentially open chromatin regions in STAG2 mutant cells (Table 2). This suggests that cohesin influences the accessibility (and possibly the function) of these REs. R1RE1 binds cohesin subunit SMC3 and CTCF, while cohesin subunit RAD21 binds with CTCF at R1RE12, and in the absence of CTCF with R1RE18. CTCF binding was also observed in R1REs 2, 10-11, 13, 15-17, and 19-21 (Table 2).

\subsection{Enhancer RNA (eRNA)}

Enhancer RNA (eRNA) has been shown to be involved in functional roles including; assisting enhancer-promoter looping formation, supporting pause-release of RNA Pol II which facilitates transcription elongation, promoting TF and co-regulator binding and aiding target gene transcription [70-80]. Although eRNA is typically used for enhancer identification, not all active enhancers produce detectable eRNA [81,82].

FANTOM5 data showed that 16 of the 21 R1REs produced eRNA in haematopoietic cells (Figure 2, Supplementary Table S1), whereas R1REs 3, 6, 7, 9 and 10 do not have any reported eRNA expression. ChromHMM labelled R1REs 7-9, 13, and 19-21 as transcriptionassociated. This may be attributed to enhancer RNA transcription, as mR1REs 8,13 , and 19-21 all produce eRNAs. It remains to be determined whether the transcription association observed in R1REs 7 and 9 is also due to enhancer RNA production.

\subsection{Single Nucleotide Polymorphism (SNP) Analysis of R1REs}

Disease-associated variants are found in REs and in genes with equal frequency [83]. More than $95 \%$ of genome-wide association studies (GWAS) single nucleotide polymorphisms (SNPs) are located in intergenic regions, of which over $75 \%$ are associated with open chromatin (DNase I HS sites) implying a strong association with REs [84]. A variant in a RE may cause differential regulation of a gene, and could be functionally equivalent to a mutation in the coding sequence of the gene itself. Recent studies have shown that alterations to REs are associated with dysregulation of oncogenic genes [85]. It is therefore possible that mutations in enhancers or insulators may change their function, and subsequently could lead to altered gene expression [86]. 
Single nucleotide polymorphisms (SNPs) are present in each of the human RUNX1 conserved REs, except R1REs 1, 9, 12, 16, 17 and 20 (Figure 2, Supplementary Table S2). SNPs were reported in R1REs 2, 3, 10, 14, 18 and 21 in haematopoietic, brain, thyroid, skin and oesophagus cells.

Of the 40 SNPs identified in the conserved R1REs, 6 had previously reported functional effects in haematopoietic cells. R1RE2 contains rs2834945, a T to C change that is predicted to affect 11 regulatory motifs including GATA2. rs2834945 affects the expression of kynurenine 3-monooxygenase (KMO) in peripheral blood monocytes [87]. KMO encodes a mitochondrial outer membrane protein that catalyses the hydroxylation of L-tryptophan metabolite, L-kynurenine, to form L-3-hydroxykynurenine [88]. High KMO expression leads to neurodegeneration [89].

R1RE3 harbours two functional SNPs: rs16993221 and rs909143. rs16993221 is associated with white blood cell count and contributes to chronic inflammation [90]. The A to T change in rs16993221 alters two regulatory motifs, BATF and IRF, which work together in immune response. The A to G change in rs909143 is also related to expression of KMO in peripheral blood monocytes [87], and is predicted to affect two regulatory motifs (NR3C1, POU2F2). R1RE18 harbours rs73900579, a $\mathrm{T}$ to $\mathrm{C}$ variant that alters two regulatory motifs and is associated with red cell distribution width [91]. R1RE21 contains two functional SNPS, rs2249650 and rs2268276; both are associated with AML susceptibility. The different SNPs are in linkage disequilibrium (LD) and change the ability of R1RE21 to act as an enhancer. A (rs2249650) G (rs2268276) bases and AA have greater enhancer capability than GA and GG. GA has the least enhancer capability. The SNPs also affect SPI1 binding capability; AG has strong SPI1 binding, GA has weak SPI1 binding, whereas AA and GG have medium SPI1 binding capability [92].

\subsection{Cancer Associated Genetic Variation Occurrence in R1REs}

Although not all SNPs found in this study have been functionally analysed, some of the R1RE SNPs were reported in patients with AML. Two AML patients had R1RE5 SNP rs2834885. One of the patients who had R1RE5 SNP rs2834885 also had three additional alterations to R1REs; R1RE2, R1RE14 SNP rs9976900 and R1RE19 SNP rs2284613. R1RE14 SNP rs9976900 has previously been associated with long non-coding RNA RUNX1-IT1 eQTL in the brain cortex [93] and was also associated with paediatric asthma [94].

Two SNPs in R1RE15 (rs933131 and rs2834716) were also found in patients with AML. Interestingly, the patient with R1RE15 rs2834716 also had the R1RE21 SNPs (rs2268276 and rs2249650) which were previously associated with AML susceptibility [92]. Five patients with malignant lymphoma had mutations within R1REs 1 and 10 that are not reported as SNPs with a minor allele frequency (MAF) of $>1 \%$. Three variants in three different patients were found in R1RE18, however, these variants are not reported as SNPs with a MAF of $>1 \%$. Four patients had R1RE10 variants chr21:g.36480715C $>$ A (rs199811665), chr21:g.36480761A >C and chr21:g.36481470C $>$ T (rs1440069314). One case of malignant myeloma reported a variant within R1RE1, chr21:g.36399191A $>$ T. Variants were also found in R1RE15 (chr21:g36359341T>G), R1RE18 (chr21:g36280880A $>$ G) and R1RE21 (chr21:g36180724G>A).

The finding that SNPs and alterations in R1REs associates with human disease raises the possibility that these regulatory elements may be important for regulation of RUNX1 and/or other genes. It is currently unclear whether these variants have a higher or lower frequency than if they occurred by chance, and a more comprehensive catalogue of genomic data would be needed to provide significance. R1RE21 SNPs were found to be associated with AML susceptibility. However, it is possible that mutations in R1REs may explain AML progression in patients who have no known protein-coding mutations. In support of this idea, data available at cBioportal [61,62] shows a wide variability in RUNX1 expression, regardless of RUNX1 mutation status (Supplementary Figure S1).

Functional analyses are necessary to determine whether sequence variation is causative of differential gene expression and consequently, disease or neoplasia. 


\subsection{Prediction the Functional Consequences of Non-Coding Variations}

The majority of the R1REs cancer associated genetic variations and SNPs identified in these regions have no functional data. Predictions of the functional consequences of R1REs cancer associated variations and SNPs highlight 7 pathogenic predicted variations (Supplementary Table S3). R1RE1 variation (chr21:g.36399191A>T), R1RE3 (rs116951441), R1RE11 (rs2834756), R1RE18 (rs73900579), R1RE19 (rs2284613) and the previously AML susceptibility associated SNPs R1RE21 (rs2249650 and rs2268276) all have prediction scores of $>0.87$. While the FATHMM algorithm assigned pathogenicity to previously uncharacterised variants, it did not predict pathogenicity for SNPs in R1RE3, R1RE10, and R1RE14 that were associated with eQTLS or other phenotypes. This highlights the importance of using several approaches to determine the effect of variants in R1REs. Importantly, FATHMM predictions reinforced the pathogenic potential of SNPs in R1RE18 and the leukaemia-associated SNPs in R1RE21. The combined analyses show that the R1RE3, R1RE18 and R1RE21 are affected by changes that have potential to be detrimental to correct gene regulation.

\section{Discussion}

In this study, we identified 12 Runx 1 regulatory regions that are conserved between human and mouse, and are likely to be important for controlling expression of human RUNX1. This analysis increased the defined total of RUNX1 enhancers in human from 9 to 21, compared with 29 known REs in mice (Figures 1 and 2 and Table 1). Previously, both mouse and human Runx1 REs were named according to their distance from the TSS (or ATG) of the P1 promoter of Runx1. Here we instead assign each of the conserved REs a number, starting with R1RE1 through R1RE21. R1RE1 was assigned to +23/+24/eR1/RE1 because it is the best characterised of the REs, with other REs named in order according to their $5^{\prime}-3^{\prime}$ location on the same strand as the Runx 1 gene. The assignation of a common identifier for enhancers conserved between human and mouse may eliminate confusion arising from different nomenclature in the numerous studies that seek to identify and characterise RUNX1 enhancers.

Of the identified R1REs, 8 interact with the RUNX1 promoters; R1REs 1, 2, 4, 10, 15, 18 and 21 have differing interactions with Runx1 P1, P2 and R1RE1 in different mouse or human cell lines (Table 1) $[23,25,27,28]$. A recent preprint describes a study in which enhancer-promoter contacts at the mouse Runx1 gene were determined step-wise during differentiation of mouse embryonic stem cells (ESC) to mesoderm and then on to HPC [66]. During mesoderm specification, the P2 promoter increased interactions with R1REs 1, 4, 6, 13 , and 18 (and additional mouse enhancers not conserved in human). Upon differentiation of mesoderm to HPC, contacts were lost with the more upstream R1REs, while contacts to both P1 and P2 were increased with R1REs 11 and 21. Concomitantly, the Runx1 gene was expressed from the P2 promoter upon differentiation to mesoderm, and both P1 and P2 upon adopting HPC identity [66]. This study therefore reinforces the assumption that conserved REs for Runx1 are important for expression of Runx1 during haematopoietic differentiation.

The regulatory activity of 15 of the 21 human R1REs has been functionally confirmed. Moreover, there is good evidence that R1REs 16 and 21 are directly involved in AML disease progression. Cheng et al. (2018) characterised R1RE15 as a silencer of RUNX1 P2 by measuring the repressive effect of various deletion/mutant R1RE15 luciferase constructs on transcription from the P2 promoter in K562, OCI-AML3 and U937 cells [28]. However, in K562 cells R1RE15 has ENCODE and ChromHMM annotations associated with enhancer activity. Regions that have both enhancer and silencer annotations may have multiple roles depending on DNA interaction partners and the cell type. The discovery of RUNX1 silencer R1RE15 resulted from characterisation of a novel $t(5 ; 21)(\mathrm{q} 13 ; \mathrm{q} 22)$ translocation involving RUNX1 that was acquired during the progression of myelodysplastic syndrome to AML in a paediatric patient [28]. This translocation did not generate RUNX1 fusion, but rather it aberrantly upregulated the P2 isoform of RUNX1. The authors state that the 
translocation facilitated upregulation of RUNX1 P2 because the silencer at R1RE15 was removed.

R1RE21 contains SNPs that are associated with AML susceptibility, and in addition, R1RE21 is the site of translocation in $\mathrm{t}(8 ; 21)$ in AML patients in which RUNX1 and ETO genes recombine. Schnake et al. (2019) identified a long non-coding RNA in R1RE21, at a site of these frequent chromosomal translocations [95]. This long non-coding RNA results in a more relaxed chromatin organisation at R1RE21 (at the location of the breakpoint). Consequently, it is possible that chromatin relaxation leads to a higher probability of double stranded breakages in myeloid cells, resulting in translocations [95].

There were no SNPS with MAF of $>1 \%$ present in R1RE1. The one detected mutation in R1RE1 (chr21:g.36399191A >T) is predicted by FATHMM to have a pathogenic function. This suggests that there is strong selection pressure to conserve R1RE1. Consistent with this, the region containing R1RE1 appears to be functionally important in haematopoietic cells. To determine the importance of R1RE1 for RUNX1 expression and function, Mill et al. (2019) deleted the P1-P2 intron of RUNX1 P1 in OCI-AML5 cells [34], which led to a strong selection against edited cells. The P1-P2 intronic region, which contains multiple R1REs, is therefore important for cell survival and RUNX1 expression.

Predictions of functional consequences of genetic variation within the R1REs estimate that 7 variations are likely to be pathogenic. Further functional analysis of the genetic variations will allow researchers to determine the roles of these R1REs in normal haematopoiesis as well as disease progression. These predictions may be an underestimation of the functional consequences of genetic variation, as the they are calculated based on available ENCODE data.

The ability to identify significant SNPs and mutations in haematopoietic cells is limited by the scarcity of whole genome sequence in individual haematopoietic cell types, AML, and other myeloid malignancy samples. Therefore, SNP frequency in R1REs could be an underestimate. The present study is limited by both the paucity of genomic sequence data of REs in normal and leukaemic cells, and the lack of data on cell type-specific chromatin status of REs. Limitations to publicly available data is likely to be the reason why we could not assign statistical significance to SNPs present in REs. Nevertheless, determining and categorising SNPs may help us understand each patient's disease progression, individual responses to drugs, or susceptibility to relapse. Some patients had SNPs at the RUNX1 locus with previously described functional effects on haematopoietic cells. However, the SNP data for myeloproliferative disorders lacks significance because the majority of SNP information comes from analysis of whole blood, rather than each specific cell type.

\section{Conclusions}

Other than R1RE15 and R1RE21 (which are linked to leukaemia), the relevance of R1RE mutations to the progression of AML is unknown. This study sets the scene for functional analyses to precisely determine how RUNX1 is regulated, including further RUNX1 chromatin interaction analyses, and CRISPR/Cas9-mediated interference with RE activity. The results of this informatics analysis also provide a rationale for screening patients with mutations in enhancer regions. By analysing deep sequencing of AML patient samples that have no identifiable mutations in the RUNX1 coding region or in other leukaemia genes, mutations in REs that lead to dysregulated RUNX1 expression may be discovered. Sequencing analyses that identify enhancer mutations may not only explain a patient's AML progression, but could provide the basis for future therapeutic targets. Understanding the regulatory landscape of RUNX1 will further increase understanding of haematopoiesis as well as identify potential new regions for driver mutations in myeloid malignancies.

Supplementary Materials: The following are available online at https:/ / www.mdpi.com/article/10 .3390 /genes12081175/s1, Figure S1: Variation in RUNX1 expression according to RUNX1 mutation status, Table S1: Cell types with R1RE RNA expression, Table S2: SNP analysis of previously identified 
R1Res. Table S3: FATHMM prediction of the functional consequences of non-coding mutations of previously identified R1REs.

Author Contributions: Conceptualization, J.A.H., J.M., J.A., J.M.O. and A.L.T.; methodology, A.L.T.; software, A.L.T. and W.S.; validation, A.L.T.; formal analysis, A.L.T. and W.S.; investigation, A.L.T.; resources, J.A.H.; data curation, J.M., J.A., W.S. and A.L.T.; writing-original draft preparation, A.L.T.; writing-review and editing, J.A.H.; visualization, A.L.T.; supervision, J.A.H., J.M., J.A. and J.M.O.; project administration, J.A.H.; funding acquisition, J.A.H. and A.L.T. All authors have read and agreed to the published version of the manuscript.

Funding: This research was funded by Cancer Research Trust New Zealand, Post-graduate scholarship, grant number GOT-1537-PGS and Health Research Council of New Zealand, grant numbers HRC 15/229 and HRC 19/415.

Institutional Review Board Statement: Not applicable.

Informed Consent Statement: Not applicable.

Data Availability Statement: Publicly available datasets were analysed in this study. These data can be found here: https: / genome.ucsc.edu/ (accessed on 30 June 2021), https: / / www.ebi.ac.uk/gwas/, https: / cancer.sanger.ac.uk/cosmic, https:/ / dice-database.org/, https:/ / pubs.broadinstitute.org/ mammals/haploreg/haploreg.php, https://gtexportal.org/home/, https:/ / gnomad.broadinstitute. org/, https:/ / dcc.icgc.org/, https:/ / www.cbioportal.org/, https:/ /www.cancer.gov/about-nci/ organization/ccg/research/structural-genomics/tcga, http:/ / bioinfo.au.tsinghua.edu.cn/dbsuper, https:/ / doi.org/10.1093/jmcb/mjz114, https:/ / doi.org/10.1038/s41588-020-0578-5.

Acknowledgments: The authors would like to thank Motomi Osato for helpful discussions and advice.

Conflicts of Interest: The authors declare no conflict of interest.

\section{References}

1. Kadauke, S.; Blobel, G.A. Chromatin loops in gene regulation. Biochim. Biophys. Acta Gene Regul. Mech. 2009, 1789, 17-25. [CrossRef] [PubMed]

2. Marsman, J.; Horsfield, J.A. Long distance relationships: Enhancer-promoter communication and dynamic gene transcription. Biochim. Biophys. Acta Gene Regul. Mech. 2012, 1819, 1217-1227. [CrossRef]

3. Villar, D.; Berthelot, C.; Aldridge, S.; Rayner, T.F.; Lukk, M.; Pignatelli, M.; Park, T.J.; Deaville, R.; Erichsen, J.T.; Jasinska, A.J. Enhancer evolution across 20 mammalian species. Cell 2015, 160, 554-566. [CrossRef] [PubMed]

4. Mifsud, B.; Tavares-Cadete, F.; Young, A.N.; Sugar, R.; Schoenfelder, S.; Ferreira, L.; Wingett, S.W.; Andrews, S.; Grey, W.; Ewels, P.A. Mapping long-range promoter contacts in human cells with high-resolution capture Hi-C. Nat. Genet. $2015,47,598$. [CrossRef] [PubMed]

5. Javierre, B.M.; Burren, O.S.; Wilder, S.P.; Kreuzhuber, R.; Hill, S.M.; Sewitz, S.; Cairns, J.; Wingett, S.W.; Várnai, C.; Thiecke, M.J. Lineage-specific genome architecture links enhancers and non-coding disease variants to target gene promoters. Cell 2016, 167, 1369-1384. [CrossRef] [PubMed]

6. $\quad$ Spieler, D.; Kaffe, M.; Knauf, F.; Bessa, J.; Tena, J.J.; Giesert, F.; Schormair, B.; Tilch, E.; Lee, H.; Horsch, M. Restless legs syndromeassociated intronic common variant in Meis1 alters enhancer function in the developing telencephalon. Genome Res. 2014, 24, 592-603. [CrossRef] [PubMed]

7. Marsman, J.; O’Neill, A.C.; Kao, B.R.; Rhodes, J.M.; Meier, M.; Antony, J.; Monnich, M.; Horsfield, J.A. Cohesin and CTCF differentially regulate spatiotemporal runx1 expression during zebrafish development. Biochim. Biophys. Acta Gene Regul. Mech. 2014, 1839, 50-61. [CrossRef]

8. Smemo, S.; Tena, J.J.; Kim, K.-H.; Gamazon, E.R.; Sakabe, N.J.; Gomez-Marin, C.; Aneas, I.; Credidio, F.L.; Sobreira, D.R.; Wasserman, N.F.; et al. Obesity-associated variants within FTO form long-range functional connections with IRX3. Nature 2014, 507, 371-375. [CrossRef]

9. Li, G.; Ruan, X.; Auerbach, R.K.; Sandhu, K.S.; Zheng, M.; Wang, P.; Poh, H.M.; Goh, Y.; Lim, J.; Zhang, J. Extensive promotercentered chromatin interactions provide a topological basis for transcription regulation. Cell 2012, 148, 84-98. [CrossRef]

10. Phillips-Cremins, J.E.; Corces, V.G. Chromatin insulators: Linking genome organization to cellular function. Mol. Cell 2013, 50, 461-474. [CrossRef]

11. Canela, A.; Maman, Y.; Jung, S.; Wong, N.; Callen, E.; Day, A.; Kieffer-Kwon, K.-R.; Pekowska, A.; Zhang, H.; Rao, S.S. Genome Organization Drives Chromosome Fragility. Cell 2017, 170, 507-521. [CrossRef] [PubMed]

12. Okuda, T.; Van Deursen, J.; Hiebert, S.W.; Grosveld, G.; Downing, J.R. AML1, the target of multiple chromosomal translocations in human leukemia, is essential for normal fetal liver hematopoiesis. Cell 1996, 84, 321-330. [CrossRef] 
13. Wang, Q.; Stacy, T.; Binder, M.; Marin-Padilla, M.; Sharpe, A.H.; Speck, N.A. Disruption of the Cbfa2 gene causes necrosis and hemorrhaging in the central nervous system and blocks definitive hematopoiesis. Proc. Natl. Acad. Sci. USA 1996, 93, 3444-3449. [CrossRef]

14. Mulloy, J.C.; Cammenga, J.; MacKenzie, K.L.; Berguido, F.J.; Moore, M.A.; Nimer, S.D. The AML1-ETO fusion protein promotes the expansion of human hematopoietic stem cells. Blood J. Am. Soc. Hematol. 2002, 99, 15-23. [CrossRef]

15. Gaidzik, V.I.; Bullinger, L.; Schlenk, R.F.; Zimmermann, A.S.; Röck, J.; Paschka, P.; Corbacioglu, A.; Krauter, J.; Schlegelberger, B.; Ganser, A. RUNX1 mutations in acute myeloid leukemia: Results from a comprehensive genetic and clinical analysis from the AML study group. J. Clin. Oncol. 2011, 29, 1364-1372. [CrossRef]

16. Schlegelberger, B.; Göhring, G.; Thol, F.; Heuser, M. Update on cytogenetic and molecular changes in myelodysplastic syndromes. Leuk. Lymphoma 2012, 53, 525-536. [CrossRef]

17. Fujita, Y.; Nishimura, M.; Taniwaki, M.; Abe, T.; Okuda, T. Identification of an alternatively spliced form of the mouse AML1/RUNX1 gene transcript AML1c and its expression in early hematopoietic development. Biochem. Biophys. Res. Commun. 2001, 281, 1248-1255. [CrossRef] [PubMed]

18. de Bruijn, M.; Dzierzak, E. Runx transcription factors in the development and function of the definitive hematopoietic system. Blood 2017, 129, 2061-2069. [CrossRef]

19. Bee, T.; Ashley, E.L.; Bickley, S.R.; Jarratt, A.; Li, P.-S.; Sloane-Stanley, J.; Göttgens, B.; de Bruijn, M.F. The mouse Runx1+ 23 hematopoietic stem cell enhancer confers hematopoietic specificity to both Runx1 promoters. Blood 2009, 113, 5121-5124. [CrossRef]

20. Nottingham, W.T.; Jarratt, A.; Burgess, M.; Speck, C.L.; Cheng, J.-F.; Prabhakar, S.; Rubin, E.M.; Li, P.-S.; Sloane-Stanley, J.; Kong-a-San, J. Runx1-mediated hematopoietic stem-cell emergence is controlled by a Gata/Ets/SCL-regulated enhancer. Blood 2007, 110, 4188-4197. [CrossRef]

21. Ng, C.E.L.; Yokomizo, T.; Yamashita, N.; Cirovic, B.; Jin, H.; Wen, Z.; Ito, Y.; Osato, M. A Runx1 intronic enhancer marks hemogenic endothelial cells and hematopoietic stem cells. Stem Cells 2010, 28, 1869-1881. [CrossRef] [PubMed]

22. Koh, C.P.; Ng, C.; Nah, G.; Wang, C.Q.; Tergaonkar, V.; Matsumura, T.; Yokomizo, T.; Suda, T.; Osato, M. Hematopoietic stem cell enhancer: A powerful tool in stem cell biology. Histol. Histopathol. 2015, 30, 661-672. [PubMed]

23. Markova, E.N.; Kantidze, O.L.; Razin, S.V. Transcriptional regulation and spatial organisation of the human AML1/RUNX1 gene. J. Cell. Biochem. 2011, 112, 1997-2005. [CrossRef]

24. Schütte, J.; Wang, H.; Antoniou, S.; Jarratt, A.; Wilson, N.K.; Riepsaame, J.; Calero-Nieto, F.J.; Moignard, V.; Basilico, S.; Kinston, S.J. An experimentally validated network of nine haematopoietic transcription factors reveals mechanisms of cell state stability. eLife 2016, 5, e11469. [CrossRef] [PubMed]

25. Marsman, J.; Thomas, A.; Osato, M.; O'Sullivan, J.M.; Horsfield, J.A. A DNA Contact Map for the Mouse Runx1 Gene Identifies Novel Haematopoietic Enhancers. Sci. Rep. 2017, 7, 13347. [CrossRef]

26. Gunnell, A.; Webb, H.M.; Wood, C.D.; McClellan, M.J.; Wichaidit, B.; Kempkes, B.; Jenner, R.G.; Osborne, C.; Farrell, P.J.; West, M.J. RUNX super-enhancer control through the Notch pathway by Epstein-Barr virus transcription factors regulates B cell growth. Nucleic Acids Res. 2016, 44, 4636-4650. [CrossRef] [PubMed]

27. Wilson, N.K.; Schoenfelder, S.; Hannah, R.; Castillo, M.S.; Schütte, J.; Ladopoulos, V.; Mitchelmore, J.; Goode, D.K.; Calero-Nieto, F.J.; Moignard, V. Integrated genome-scale analysis of the transcriptional regulatory landscape in a blood stem/progenitor cell model. Blood 2016, 127, e12-e23. [CrossRef]

28. Cheng, C.-K.; Wong, T.H.Y.; Wan, T.S.K.; Wang, A.Z.; Chan, N.P.H.; Chan, N.C.N.; Li, C.-K.; Ng, M.H.L. RUNX1 upregulation via disruption of long-range transcriptional control by a novel $\mathrm{t}(5 ; 21)(\mathrm{q} 13 ; \mathrm{q} 22)$ translocation in acute myeloid leukemia. Mol. Cancer 2018, 17, 133. [CrossRef]

29. Vukadin, L.; Kim, J.-H.; Park, E.Y.; Stone, J.K.; Ungerleider, N.; Baddoo, M.C.; Kong, H.K.; Richard, A.; Tran, J.; Giannini, H. SON inhibits megakaryocytic differentiation via repressing RUNX1 and the megakaryocytic gene expression program in acute megakaryoblastic leukemia. Cancer Gene Ther. 2020. [CrossRef]

30. Cauchy, P.; James, S.R.; Zacarias-Cabeza, J.; Ptasinska, A.; Imperato, M.R.; Assi, S.A.; Piper, J.; Canestraro, M.; Hoogenkamp, M.; Raghavan, M. Chronic FLT3-ITD signaling in acute myeloid leukemia is connected to a specific chromatin signature. Cell Rep. 2015, 12, 821-836. [CrossRef]

31. Ortt, K.; Raveh, E.; Gat, U.; Sinha, S. A chromatin immunoprecipitation screen in mouse keratinocytes reveals Runx1 as a direct transcriptional target of $\Delta$ Np63. J. Cell. Biochem. 2008, 104, 1204-1219. [CrossRef]

32. Fitch, S.R.; Kapeni, C.; Tsitsopoulou, A.; Wilson, N.K.; Göttgens, B.; de Bruijn, M.F.; Ottersbach, K. Gata3 targets Runx1 in the embryonic haematopoietic stem cell niche. IUBMB Life 2020, 72, 45-52. [CrossRef]

33. Harland, L.T.; Simon, C.S.; Senft, A.D.; Costello, I.; Greder, L.; Imaz-Rosshandler, I.; Göttgens, B.; Marioni, J.C.; Bikoff, E.K.; Porcher, C. The T-box transcription factor Eomesodermin governs haemogenic competence of yolk sac mesodermal progenitors. Nat. Cell Biol. 2021, 23, 61-74. [CrossRef] [PubMed]

34. Mill, C.P.; Fiskus, W.; DiNardo, C.D.; Qian, Y.; Raina, K.; Rajapakshe, K.; Perera, D.; Coarfa, C.; Kadia, T.M.; Khoury, J.D. RUNX1-targeted therapy for AML expressing somatic or germline mutation in RUNX1. Blood 2019, 134, 59-73. [CrossRef] [PubMed] 
35. Orlando, G.; Law, P.J.; Cornish, A.J.; Dobbins, S.E.; Chubb, D.; Broderick, P.; Litchfield, K.; Hariri, F.; Pastinen, T.; Osborne, C.S. Promoter capture Hi-C-based identification of recurrent noncoding mutations in colorectal cancer. Nat. Genet. 2018, 50, 1375-1380. [CrossRef] [PubMed]

36. Puente, X.S.; Beà, S.; Valdés-Mas, R.; Villamor, N.; Gutiérrez-Abril, J.; Martín-Subero, J.I.; Munar, M.; Rubio-Pérez, C.; Jares, P.; Aymerich, M. Non-coding recurrent mutations in chronic lymphocytic leukaemia. Nature 2015, 526, 519-524. [CrossRef] [PubMed]

37. Mansour, M.R.; Abraham, B.J.; Anders, L.; Berezovskaya, A.; Gutierrez, A.; Durbin, A.D.; Etchin, J.; Lawton, L.; Sallan, S.E.; Silverman, L.B. An oncogenic super-enhancer formed through somatic mutation of a noncoding intergenic element. Science 2014, 346, 1373-1377. [CrossRef]

38. Cornish, A.J.; Hoang, P.H.; Dobbins, S.E.; Law, P.J.; Chubb, D.; Orlando, G.; Houlston, R.S. Identification of recurrent noncoding mutations in B-cell lymphoma using capture Hi-C. Blood Adv. 2019, 3, 21-32. [CrossRef] [PubMed]

39. Kent, W.J.; Sugnet, C.W.; Furey, T.S.; Roskin, K.M.; Pringle, T.H.; Zahler, A.M.; Haussler, D. The Human Genome Browser at UCSC. Genome Res. 2002, 12, 996-1006. [CrossRef] [PubMed]

40. Waterston, R.H.; Lindblad-Toh, K.; Birney, E.; Rogers, J.; Abril, J.F.; Agarwal, P.; Agarwala, R.; Ainscough, R.; Alexandersson, M.; An, P.; et al. Initial sequencing and comparative analysis of the mouse genome. Nature 2002, 420, 520-562. [CrossRef]

41. Barski, A.; Cuddapah, S.; Cui, K.; Roh, T.-Y.; Schones, D.E.; Wang, Z.; Wei, G.; Chepelev, I.; Zhao, K. High-resolution profiling of histone methylations in the human genome. Cell 2007, 129, 823-837. [CrossRef]

42. Rosenbloom, K.R.; Sloan, C.A.; Malladi, V.S.; Dreszer, T.R.; Learned, K.; Kirkup, V.M.; Wong, M.C.; Maddren, M.; Fang, R.; Heitner, S.G.; et al. ENCODE Data in the UCSC Genome Browser: Year 5 update. Nucleic Acids Res. 2013, 41, D56-D63. [CrossRef]

43. Raney, B.J.; Dreszer, T.R.; Barber, G.P.; Clawson, H.; Fujita, P.A.; Wang, T.; Nguyen, N.; Paten, B.; Zweig, A.S.; Karolchik, D.; et al. Track data hubs enable visualization of user-defined genome-wide annotations on the UCSC Genome Browser. Bioinformatics 2014, 30, 1003-1005. [CrossRef]

44. Kent, W.J. BLAT-The BLAST-Like Alignment Tool. Genome Res. 2002, 12, 656-664. [CrossRef]

45. Altschul, S.F.; Gish, W.; Miller, W.; Myers, E.W.; Lipman, D.J. Basic local alignment search tool. J. Mol. Biol. 1990, 215, 403-410. [CrossRef]

46. Andersson, R.; Gebhard, C.; Miguel-Escalada, I.; Hoof, I.; Bornholdt, J.; Boyd, M.; Chen, Y.; Zhao, X.; Schmidl, C.; Suzuki, T. An atlas of active enhancers across human cell types and tissues. Nature 2014, 507, 455-461. [CrossRef] [PubMed]

47. Lizio, M.; Harshbarger, J.; Shimoji, H.; Severin, J.; Kasukawa, T.; Sahin, S.; Abugessaisa, I.; Fukuda, S.; Hori, F.; Ishikawa-Kato, S. Gateways to the FANTOM5 promoter level mammalian expression atlas. Genome Biol. 2015, 16, 22. [CrossRef] [PubMed]

48. Kellis, M.; Ernst, J. Chromatin-state discovery and genome annotation with ChromHMM. Nat. Protoc. 2017, $12,2478$.

49. Khan, A.; Zhang, X. dbSUPER: A database of super-enhancers in mouse and human genome. Nucleic Acids Res. 2016, 44, D164-D171. [CrossRef]

50. Pang, B.; Snyder, M.P. Systematic identification of silencers in human cells. Nat. Genet. 2020, 52, 254-263. [CrossRef] [PubMed]

51. Antony, J.; Gimenez, G.; Taylor, T.; Khatoon, U.; Day, R.; Morison, I.M.; Horsfield, J.A. BET inhibition prevents aberrant RUNX1 and ERG transcription in STAG2 mutant leukaemia cells. J. Mol. Cell Biol. 2020, 12, 397-399. [CrossRef]

52. Buniello, A.; MacArthur, J.A.L.; Cerezo, M.; Harris, L.W.; Hayhurst, J.; Malangone, C.; McMahon, A.; Morales, J.; Mountjoy, E.; Sollis, E. The NHGRI-EBI GWAS Catalog of published genome-wide association studies, targeted arrays and summary statistics 2019. Nucleic Acids Res. 2019, 47, D1005-D1012. [CrossRef]

53. Tate, J.G.; Bamford, S.; Jubb, H.C.; Sondka, Z.; Beare, D.M.; Bindal, N.; Boutselakis, H.; Cole, C.G.; Creatore, C.; Dawson, E. COSMIC: The catalogue of somatic mutations in cancer. Nucleic Acids Res. 2019, 47, D941-D947. [CrossRef]

54. Schmiedel, B.J.; Singh, D.; Madrigal, A.; Valdovino-Gonzalez, A.G.; White, B.M.; Zapardiel-Gonzalo, J.; Ha, B.; Altay, G.; Greenbaum, J.A.; McVicker, G. Impact of genetic polymorphisms on human immune cell gene expression. Cell 2018, 175, 1701-1715. [CrossRef]

55. Chandra, V.; Bhattacharyya, S.; Schmiedel, B.J.; Madrigal, A.; Gonzalez-Colin, C.; Fotsing, S.; Crinklaw, A.; Seumois, G.; Mohammadi, P.; Kronenberg, M. Promoter-interacting expression quantitative trait loci are enriched for functional genetic variants. Nat. Genet. 2021, 53, 110-119. [CrossRef]

56. Ward, L.D.; Kellis, M. HaploReg v4: Systematic mining of putative causal variants, cell types, regulators and target genes for human complex traits and disease. Nucleic Acids Res. 2016, 44, D877-D881. [CrossRef]

57. Karczewski, K.J.; Francioli, L.C.; Tiao, G.; Cummings, B.B.; Alföldi, J.; Wang, Q.; Collins, R.L.; Laricchia, K.M.; Ganna, A.; Birnbaum, D.P. The mutational constraint spectrum quantified from variation in 141,456 humans. Nature 2020, 581, 434-443. [CrossRef]

58. Fadason, T.; Ekblad, C.; Ingram, J.R.; Schierding, W.S.; O'Sullivan, J.M. Physical interactions and expression quantitative traits loci identify regulatory connections for obesity and type 2 diabetes associated SNPs. Front. Genet. 2017, 8, 150. [CrossRef] [PubMed]

59. Zhang, J.; Baran, J.; Cros, A.; Guberman, J.M.; Haider, S.; Hsu, J.; Liang, Y.; Rivkin, E.; Wang, J.; Whitty, B.; et al. International Cancer Genome Consortium Data Portal-A one-stop shop for cancer genomics data. Database J. Biol. Databases Curation 2011, 2011, bar026. [CrossRef] [PubMed]

60. Hudson, T.J.; Jennings, J.L. Abstract 4278: International Cancer Genome Consortium (ICGC). Cancer Res. 2014, 74, 4278. [CrossRef]

61. Gao, J.; Aksoy, B.A.; Dogrusoz, U.; Dresdner, G.; Gross, B.; Sumer, S.O.; Sun, Y.; Jacobsen, A.; Sinha, R.; Larsson, E.; et al. Integrative analysis of complex cancer genomics and clinical profiles using the cBioPortal. Sci. Signal. 2013, 6, pl1. [CrossRef] 
62. Cerami, E.; Gao, J.; Dogrusoz, U.; Gross, B.E.; Sumer, S.O.; Aksoy, B.A.; Jacobsen, A.; Byrne, C.J.; Heuer, M.L.; Larsson, E.; et al. The cBio Cancer Genomics Portal: An open platform for exploring multidimensional cancer genomics data. Cancer Discov. 2012, 2, 401-404. [CrossRef] [PubMed]

63. The Cancer Genome Atlas Research Network (CGARN). Genomic and epigenomic landscapes of adult de novo acute myeloid leukemia. N. Engl. J. Med. 2013, 368, 2059-2074. [CrossRef] [PubMed]

64. Rogers, M.F.; Shihab, H.A.; Mort, M.; Cooper, D.N.; Gaunt, T.R.; Campbell, C. FATHMM-XF: Accurate prediction of pathogenic point mutations via extended features. Bioinformatics 2018, 34, 511-513. [CrossRef] [PubMed]

65. Shihab, H.A.; Rogers, M.F.; Gough, J.; Mort, M.; Cooper, D.N.; Day, I.N.; Gaunt, T.R.; Campbell, C. An integrative approach to predicting the functional effects of non-coding and coding sequence variation. Bioinformatics 2015, 31, 1536-1543. [CrossRef]

66. Owens, D.D.; Anselmi, G.; Oudelaar, A.M.; Downes, D.J.; Cavallo, A.; Harman, J.R.; Schwessinger, R.; Bucakci, A.; Greder, L.; De Ornellas, S. Dynamic Runx1 chromatin boundaries affect gene expression in hematopoietic development. bioRxiv 2021. [CrossRef]

67. Tang, X.; Sun, L.; Wang, G.; Chen, B.; Luo, F. RUNX1: A Regulator of NF-кB Signaling in Pulmonary Diseases. Curr. Protein Pept. Sci. 2018, 19, 172-178. [CrossRef]

68. Zhu, Q.; Gao, P.; Tober, J.; Bennett, L.; Chen, C.; Uzun, Y.; Li, Y.; Howell, E.D.; Mumau, M.; Yu, W. Developmental trajectory of prehematopoietic stem cell formation from endothelium. Blood J. Am. Soc. Hematol. 2020, 136, 845-856. [CrossRef] [PubMed]

69. Kerenyi, M.A.; Shao, Z.; Hsu, Y.-J.; Guo, G.; Luc, S.; O’Brien, K.; Fujiwara, Y.; Peng, C.; Nguyen, M.; Orkin, S.H. Histone demethylase Lsd1 represses hematopoietic stem and progenitor cell signatures during blood cell maturation. eLife 2013, 2, e00633. [CrossRef] [PubMed]

70. Melo, C.A.; Drost, J.; Wijchers, P.J.; van de Werken, H.; de Wit, E.; Vrielink, J.A.O.; Elkon, R.; Melo, S.A.; Léveillé, N.; Kalluri, R. eRNAs are required for p53-dependent enhancer activity and gene transcription. Mol. Cell 2013, 49, 524-535. [CrossRef] [PubMed]

71. Lam, M.T.; Cho, H.; Lesch, H.P.; Gosselin, D.; Heinz, S.; Tanaka-Oishi, Y.; Benner, C.; Kaikkonen, M.U.; Kim, A.S.; Kosaka, M. Rev-Erbs repress macrophage gene expression by inhibiting enhancer-directed transcription. Nature 2013, 498, 511-515. [CrossRef]

72. Li, W.; Notani, D.; Ma, Q.; Tanasa, B.; Nunez, E.; Chen, A.Y.; Merkurjev, D.; Zhang, J.; Ohgi, K.; Song, X. Functional roles of enhancer RNAs for oestrogen-dependent transcriptional activation. Nature 2013, 498, 516-520. [CrossRef] [PubMed]

73. Lai, F.; Orom, U.A.; Cesaroni, M.; Beringer, M.; Taatjes, D.J.; Blobel, G.A.; Shiekhattar, R. Activating RNAs associate with Mediator to enhance chromatin architecture and transcription. Nature 2013, 494, 497-501. [CrossRef]

74. Tsai, P.-F.; Dell'Orso, S.; Rodriguez, J.; Vivanco, K.O.; Ko, K.-D.; Jiang, K.; Juan, A.H.; Sarshad, A.A.; Vian, L.; Tran, M. A muscle-specific enhancer RNA mediates cohesin recruitment and regulates transcription in trans. Mol. Cell 2018, 71, 129-141. [CrossRef]

75. Panigrahi, A.K.; Foulds, C.E.; Lanz, R.B.; Hamilton, R.A.; Yi, P.; Lonard, D.M.; Tsai, M.-J.; Tsai, S.Y.; O'Malley, B.W. SRC-3 coactivator governs dynamic estrogen-induced chromatin looping interactions during transcription. Mol. Cell 2018, 70, 679-694. [CrossRef]

76. Sigova, A.A.; Abraham, B.J.; Ji, X.; Molinie, B.; Hannett, N.M.; Guo, Y.E.; Jangi, M.; Giallourakis, C.C.; Sharp, P.A.; Young, R.A. Transcription factor trapping by RNA in gene regulatory elements. Science 2015, 350, 978-981. [CrossRef]

77. Bose, D.A.; Donahue, G.; Reinberg, D.; Shiekhattar, R.; Bonasio, R.; Berger, S.L. RNA binding to CBP stimulates histone acetylation and transcription. Cell 2017, 168, 135-149. [CrossRef] [PubMed]

78. Rahnamoun, H.; Lee, J.; Sun, Z.; Lu, H.; Ramsey, K.M.; Komives, E.A.; Lauberth, S.M. RNAs interact with BRD4 to promote enhanced chromatin engagement and transcription activation. Nat. Struct. Mol. Biol. 2018, 25, 687-697. [CrossRef]

79. Hou, T.Y.; Kraus, W.L. Spirits in the Material World: Enhancer RNAs in Transcriptional Regulation. Trends Biochem. Sci. 2020, 46, 138-153. [CrossRef]

80. Schaukowitch, K.; Joo, J.-Y.; Liu, X.; Watts, J.K.; Martinez, C.; Kim, T.-K. Enhancer RNA facilitates NELF release from immediate early genes. Mol. Cell 2014, 56, 29-42. [CrossRef] [PubMed]

81. Mikhaylichenko, O.; Bondarenko, V.; Harnett, D.; Schor, I.E.; Males, M.; Viales, R.R.; Furlong, E.E. The degree of enhancer or promoter activity is reflected by the levels and directionality of eRNA transcription. Genes Dev. 2018, 32, 42-57. [CrossRef] [PubMed]

82. Sartorelli, V.; Lauberth, S.M. Enhancer RNAs are an important regulatory layer of the epigenome. Nat. Struct. Mol. Biol. 2020, 27, 521-528. [CrossRef] [PubMed]

83. Ernst, J.; Kheradpour, P.; Mikkelsen, T.S.; Shoresh, N.; Ward, L.D.; Epstein, C.B.; Zhang, X.; Wang, L.; Issner, R.; Coyne, M. Mapping and analysis of chromatin state dynamics in nine human cell types. Nature 2011, 473, 43-49. [CrossRef] [PubMed]

84. Maurano, M.T.; Humbert, R.; Rynes, E.; Thurman, R.E.; Haugen, E.; Wang, H.; Reynolds, A.P.; Sandstrom, R.; Qu, H.; Brody, J. Systematic localization of common disease-associated variation in regulatory DNA. Science 2012, 337, 1190-1195. [CrossRef]

85. Zhang, Y.; Chen, F.; Fonseca, N.A.; He, Y.; Fujita, M.; Nakagawa, H.; Zhang, Z.; Brazma, A.; Creighton, C.J. High-coverage wholegenome analysis of 1220 cancers reveals hundreds of genes deregulated by rearrangement-mediated cis-regulatory alterations. Nat. Commun. 2020, 11, 736. [CrossRef]

86. Stranger, B.E.; Nica, A.C.; Forrest, M.S.; Dimas, A.; Bird, C.P.; Beazley, C.; Ingle, C.E.; Dunning, M.; Flicek, P.; Koller, D. Population genomics of human gene expression. Nat. Genet. 2007, 39, 1217-1224. [CrossRef] 
87. Zeller, T.; Wild, P.; Szymczak, S.; Rotival, M.; Schillert, A.; Castagne, R.; Maouche, S.; Germain, M.; Lackner, K.; Rossmann, H. Genetics and beyond-the transcriptome of human monocytes and disease susceptibility. PLoS ONE 2010, 5, e10693. [CrossRef]

88. Alberati-Giani, D.; Cesura, A.M.; Broger, C.; Warren, W.D.; Röver, S.; Malherbe, P. Cloning and functional expression of human kynurenine 3-monooxygenase. FEBS Lett. 1997, 410, 407-412. [CrossRef]

89. Breton, J.; Avanzi, N.; Magagnin, S.; Covini, N.; Magistrelli, G.; Cozzi, L.; Isacchi, A. Functional characterization and mechanism of action of recombinant human kynurenine 3-hydroxylase. Eur. J. Biochem. 2000, 267, 1092-1099. [CrossRef]

90. Kong, M.; Lee, C. Genetic associations with C-reactive protein level and white blood cell count in the KARE study. Int. J. Immunogenet. 2013, 40, 120-125. [CrossRef] [PubMed]

91. Kichaev, G.; Bhatia, G.; Loh, P.-R.; Gazal, S.; Burch, K.; Freund, M.K.; Schoech, A.; Pasaniuc, B.; Price, A.L. Leveraging polygenic functional enrichment to improve GWAS power. Am. J. Hum. Genet. 2019, 104, 65-75. [CrossRef]

92. Xu, X.; Ren, X.; Wang, H.; Zhao, Y.; Yi, Z.; Wang, K.; Zhang, S.; Wang, L.; Samuelson, D.J.; Hu, Z. Identification and functional analysis of acute myeloid leukemia susceptibility associated single nucleotide polymorphisms at non-protein coding regions of RUNX1. Leuk. Lymphoma 2016, 57, 1442-1449. [CrossRef] [PubMed]

93. Heinzen, E.L.; Ge, D.; Cronin, K.D.; Maia, J.M.; Shianna, K.V.; Gabriel, W.N.; Welsh-Bohmer, K.A.; Hulette, C.M.; Denny, T.N.; Goldstein, D.B. Tissue-specific genetic control of splicing: Implications for the study of complex traits. PLoS Biol. 2008, 6, e1000001. [CrossRef] [PubMed]

94. Haley, K.J.; Lasky-Su, J.; Manoli, S.E.; Smith, L.A.; Shahsafaei, A.; Weiss, S.T.; Tantisira, K. RUNX transcription factors: Association with pediatric asthma and modulated by maternal smoking. Am. J. Physiol. Lung Cell. Mol. Physiol. 2011, 301, L693-L701. [CrossRef] [PubMed]

95. Schnake, N.; Hinojosa, M.; Gutiérrez, S. Identification of a novel long non-coding RNA within RUNX1 intron 5. Hum. Genom. 2019, 13, 33. [CrossRef] [PubMed] 